\title{
ТЕХНИКО-ТЕХНОЛОГИЧЕСКИЕ
}

ИННОВАЦИИ

DOI: http://dx.doi.org/10.15688/jvolsu10.2016.1.4

УДК 633.88

ББК 53.52

\section{PECULIARITIES OF THE HEAVY METALS ACCUMULATION IN THE PLANTS OF MEDICINAL CROPS UNDER THE CONDITIONS OF THE FOREST-STEPPE}

\section{Olga Ivanovna Rudnik-Ivashchenko}

Doctor of Agricultural Sciences, Institute of Horticulture,

National Academy of Agrarian Sciences of Ukraine

rudnik2015@ukr.net

Sadovaya St., 6, 03027 Kyiv, Ukraine

\section{Lyudmila Nikolaevna Mykhalska}

Candidate of Biological Sciences, Institute of Plant Physiology and Genetics, National Academy of Sciences of Ukraine VictorSchwartau@gmail.com

Vasilkovskaya St., 31/17, 03022 Kyiv, Ukraine

\section{Viktor Valentinovich Schwartau}

Doctor of Biological Sciences,

Institute of Plant Physiology and Genetics,

National Academy of Sciences of Ukraine

VictorSchwartau@gmail.com

Vasilkovskaya St., 31/17, 03022 Kyiv, Ukraine

\begin{abstract}
The role of chemical elements with a valence of two or more is important for the living organism, as just they ensure the action of enzymes - proteins, catalysts of biochemical reactions. The atoms of such elements are components of the active groups of complex proteins. Accordingly, in low amounts, such elements are necessary for plants and all living things. At the
\end{abstract}


same time, increased concentrations of these elements are disastrous for living organisms. Therefore, the study of the heavy metal biological action became a separate branch of the science.

Trophic chains contribute to the increase of the concentration and accumulation of heavy metals in organisms - consuments. That affects adversely both animals and human beings. Human activity creates the processes of the environmental contamination by heavy metals and undesirable chemical compounds. For example, the derricks of power and transport systems are powerful sources of atmospheric heavy metals: $\mathrm{Pb}, \mathrm{Mn}, \mathrm{Fe}$, and others, as well as of such compounds as benspiren, oxides of nitrogen and carbon, and the like.

The monitoring of the heavy metals concentration in the environment, particularly in the food and feeds is very important, for it makes it possible to take steps timely aimed at preserving the purity of the environment and human health. The information about the content of heavy metals in dry vegetative mass and other medicinal plants components is of great importance as well.

Key words: medicinal plant, dragonhead, mustard, permissible coefficient, dry vegetative mass, chemical elements.

\section{Introduction}

The plant world is diverse and unique. The estimated number of plant species on the planet today is over 270 thousand. The established amount of number of those known to science is more than 220 thousand. Among them 81 thousand species are described and partially investigated. All the botanical species are unrepeatable natural biochemical laboratories that are capable of synthesizing unique organic compounds in the complex metabolic processes during the plant vital activity.

Unique richness in medicinal plants is peculiar for humid tropical forests. According to expert evaluation of well-known researchers just this climatic zone can provide mankind with effective medicines of natural origin against many ailments. Most of those drugs are still waiting for their investigators both of scientists - botanists and pharmacologists and physicians. Currently, less than one percent of the species of tropical forests plants have been studied on the possibilities of their practical use. For example, biologically active plant substances - alkaloids have already found wide use in medicine and their potential is far from being exhausted. Alkaloids display various effect and are used in cardiac and respiratory stimulants, preparations which increase (or decrease), raise (or lower) arterial blood pressure and can expand pupils of eyes and inhibit the growth of tumors, hallucinogens in antileukemia, antimalarials medial, muscle relaxants, local and general anesthetics. Among 4350 known alkaloids biological properties only about $40 \%$ of them were researched. The plants which are biologically active and valuable substances prove to occur in tropical plant twice as often as compared with plants of the temperate climatic zone if Cinchona synthesizing quinine were not found the jungles of the eastern Andes, the inhabitants of tropics, subtropics and a significant number of residents in the temperate latitudes would be simply doomed to suffering from malaria. This terrible disease affects more than 200 million people. In Africa alone, malaria is a cause of over one million deaths per year.

The flora and its pharmaceutical potential have been explored relatively more fully in the temperate zone of the planet. It is the healing properties of primarily wild plant species, the folk medicine in Europe, Asia, Africa and other continents is based on [12].

Medicinal plant raw material is widely used in scientific medical practice too. In the modern pharmacology, along the wide use of synthetic drugs about $44 \%$ of all the medicines are remedies based on medicinal plants. Those plants traditionally are both of natural origin and can be grown in the process of their taming.

In Ukraine medicinal plants are cultivated annually on $3.5-4.0$ thousand ha $[3 ; 8]$. This is a very small area as compared to the demand of the inland pharmacology. There are many reasons for this situation. One of them is an increased requirement for cultivation and quality of medicinal plant raw material. Taking into consideration that Ukraine is mainly an agricultural country with such a small area under medicinal 
plants, this industry is formally absent. It affects negatively not only inland manufacturing associated with the cultivation, processing and consumption of medicinal plants products. This is a much wider problem of the world scale. After all, Ukraine has favorable conditions for those plants cultivation - the climate and arable lands, which are valuable (a large part of them is black soil which is absent in many other countries) and rich in natural micro- and macroelements.

A number of Ukrainian research institutions work on ensuring the inland pharmaceutical production with high-quality raw materials of medicinal plants and on spreading of their range. Over $45 \%$ of all the drugs produced in Ukraine, and $75 \%$ of inland pharmaceuticals intended for the treatment and prevention of cardiovascular on liver diseases and those of the gastrointestinal tract, are manufactured from raw material, cultivated in the fields of our country [5].

In Ukraine regulatory mechanisms that contribute to the development of this industry remain untapped. In recent years, registration of plant protection means for the use on medicinal plants is not carried out, state subsidies for the medicinal plant growing are not listed contrary to other countries. Despite these problems, the production of medicinal plant raw materials is on rise, and the demand of pharmaceutical companies is increasingly focused on high quality material.

According to the international standards, pharmaceutical material must come from sources that are subjected to proper monitoring and, in practice, apply scientifically based technologies of cultivation. The constancy and reproducibility of the quality of medicinal raw plant, which is used for medical purposes, are the most important factors of the clinical efficacy and reproducibility of the pharmacological effect of preparations based on it. Practice shows that the quality of the raw material supplied to the pharmaceutical companies from different suppliers has significant differences, and depends largely on the growth conditions and the collection site.

The problems of the development and improvement of the elements of the technology of medicinal crops cultivation that would meet the requirements to the raw materials quality, are studied by the scientists of the Institute of Horticulture of the National Academy of Agrarian Sciences (IH of NAAS) of Ukraine. The results of these studies demondtrate the accumulation of heavy metals in medicinal plants.

The formation and accumulation of biologically active substances by medicinal plants is a dynamic process changing in ontogeny, and also depending on numerous environmental factors, including anthropogenic ones. In addition, a number of dangerous pollutants - heavy metals, is high toxic and can be included into the biological cycle and accumulated in the human organism. Therefore, it seems topical to study the peculiarities of the heavy metals migration in the system "soil - medicinal plant - period of dry vegetative mass storage" in to the biological cycle and accumulation of harmful chemical elements in the human.

\section{Materials and Methodology}

The research were carried out at the Institute of Horticulture of the National Academy of Agrarian Sciences and Institute of Physiology and Genetics of the National Academy of Sciences of Ukraine during 2012-2014. The field investigations were conducted under the conditions of stationary in the laboratories of floral, ornamental, medicinal and oil crops of IH of NAAS. The relief of the plot is flat. The soil is dark gray podzolized, medium loamy on carbonate loess, typical for the Northern part of the Lisosteppe of Ukraine.

The soil analysis was carried out in the laboratory of agrochemistry of the Institute of Horticulture of NAAS. The humus content in the arable layer $(0-40 \mathrm{~cm})$ was $2.3 \%$, easily hydrolyable nitrogen [6] 78.4-98.0 mg / kg, of mobile phosphorus forms $93.2-180.9 \mathrm{mg} / \mathrm{kg}$, exchangeable potassium [9] 106.1-202.8 mg / kg. The reaction of the soil solution is acidic ( $\mathrm{pH}$ is 5.3-5.8 and 5.5-6.1 respectively).

The objects of the study were the plants of blessed milk thistle (Silybum marianum (L.) Gaertn.) (Fig. 1), white mustard (Sinapis alba (L.)) (Fig. 2), black mustard (Brassica nigra (L.)) (Fig. 3), Moldovan dragonhead (Dracocephalum moldavica L.) (Fig. 4), Austrian dragonhead (Dracocephalum austriacum L.) (Fig. 5). These crops are very different concerning both botanical characteristics and biological peculiarities, but their plants are in demand in the pharmacological industry. 


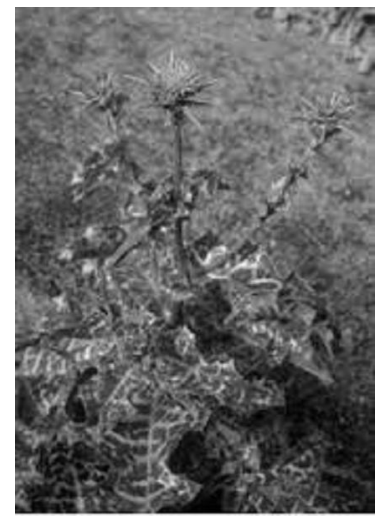

Fig. 1. Silybum marianum (L.) Gaertn.

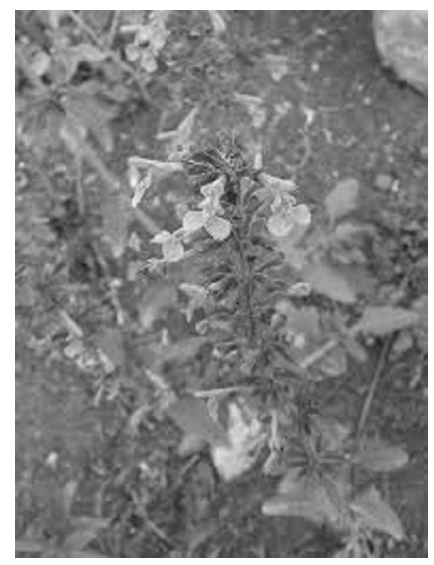

Fig. 4. Dracocephalum moldavica L.

The plant of the experiments foresaw crop alternation in the short-term field rotational, and included the following treatments for blessed milk thistle - Echinacea purpurea (Echinacea purpurea) - wild camomile (Matricaria recutita) - clary sage (Salviasclarea L.). The cultivation of these crops did not foresee fertilizing and pesticides usage.

It is seeding rate and plant stand the cultivation of these crops did not foresee fertilizing and pesticides usage special role in the formation of the thistle bush size, leaf surface, weight of 1,000 seeds, crop structure and yield. In this regard, the experiment was established in the wide - row method with innerrow spaces of $60-70 \mathrm{~cm}$ and a seeding rate of $2.0-2.5 \mathrm{~kg} / \mathrm{ha}$ of the quality standardized seeds that ensured optimal plant stand of 7-8 plants per 1 linear meter of a row.

The experimental plan for growing mustard foresaw the crop alternation in the short rotational field rotation, and it was as follows: Echinacea purpurea wild camomile (Matricaria recutita),

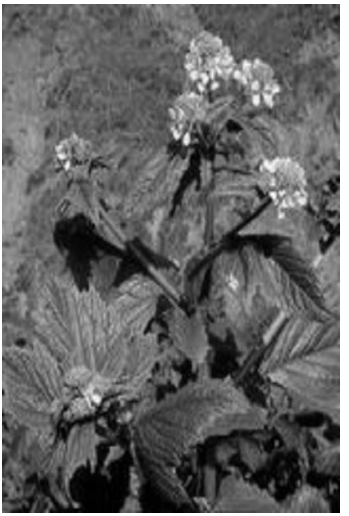

Fig. 3. Brassica nigra (L.)

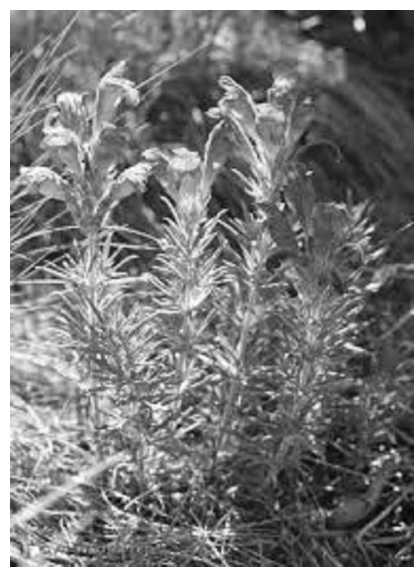

Fig. 5. Dracocephalum austriacum L.

blessed milk thistle (Silybumm arianum (L.)) Gaertn for white mustard, amaranth (Amaranthus L.), marshmallow (Althaea officinalis), tarragon (Altemisia dracunculus L.) for black mustard. However, the cultivation of these crops did not foresee fertilizing and pesticide treatment.

The experiments were established on 4-line sections $2 \mathrm{~m}$ long, with row spacing of $15 \mathrm{~cm}$. Sowing was carried out in the continuous line method. The seeding rate was $10 \mathrm{~kg} / \mathrm{ha}$, planting depth $4-5 \mathrm{~cm}$.

The plant of the experiment on growing dragonhead was as follows: the predecessor was China aster (Callistephus chinensis (L.) Nees), the seeds were sown to a depth of $2-3 \mathrm{~cm}$ on the 4-line sections $2 \mathrm{~m}$ long, with inner-row spaces of $50 \mathrm{~cm}$. The thickened stands were thinned with the formation of inner plant distance of 8-10 cm.

The tending of crop during all the research years lay in 2-3-fold inter-row hoeing and removing weeds. Watering during the growing season was carried out only in a long period without precipitations, mainly in the July of 2014, because 
that year and 2012 were not very favourable for growing plants due to very high temperatures. The sum of effective temperatures during the vegetation season ranged on average from 2301.9 (2014) to 2228.2 (2012). Despite the sufficient precipitation amount, except in July of 2014, the plants of the studied crops were behind in growth and development. That caused the delay of the flowering start by 3-5 days; break of the duration of mass flowering, of the seed formation and maturation, reduction of the seed production level.

The spring of 2013 was characterized by the decrease of temperature to $-3.3{ }^{\circ} \mathrm{C}$ in the third decade of March and rather cold weather in the first decade of April $\left(+3.7^{\circ} \mathrm{C}\right)$. This weather caused a delay in seeds sowing. But favourable conditions at the end of May and in June had a positive effect on plant growth and development.

The peculiarities of the plants development were studied and their morphological description carried out using the conventional methods as well as the atlas and determinant plants [8]. Samples for biometric research during the flowering period were taken from 10 plants. The data obtained were processed statistically using the program Microsoft Excel-2010.

The analysis of the heavy metals content in raw material, seeds and oil was carried out at the Institute of Physiology and Genetics of the National Academy of Sciences of Ukraine. The chemical elements content in the plants in test samples was determined with the use of the method ISR-MS on the emission mass spectrometer Agilent 7700x. The samples were dried to a dry mass and ached in the nitric acid by means of the microwave test preparation Milestone Start D. The obtained extract was adjusted to $50 \mathrm{ml}$ using $1 \mathrm{st}$ grade water (18 MW), prepared on the water purification system ScholarUV NexUp 1000 (Human Corporation, Korea).

The results of the experiments were processed statistically according to standard methods [9], using Exel and with the mathematical processing of the data obtained applying the professional software package for the statistical analysis Statistica 8.0.

\section{Results and discussion}

The researched plants belong to different botanical genera, but they all are widely applied in medicine. For example, blessed milk thistle is used in folk and official medicine for not one Millennium, as a plant that has effective healing properties. It belongs to the aster family and is one of the most beautiful and largest species of bristle thistle. This culture is widespread in the Caucasus and Central Asia. Now it is winning sympathy of our gardeners and horticulturists because of its unpretentiousness to the growing conditions and, above all, its therapeutic effect on many human organs. In this medicinal plant seeds, juice of leaves and stems, roots are medicinal. Many preparations are produced from the seeds of blessed milk thistle for the treatment of various diseases. Therefore it is important to know how the raw material of this plant grown in the foreststeppe of Ukraine, meets the requirements for its use and processing for drugs [10].

With regard to the mustard plants, the two species are very similar and are grown to get their seeds. The history of mustard is very ancient, and although its plants were used in ancient Greece and Rome, Asia can be considered as its birthplace [11].

Mustard is an annual herbaceous cold resistant plant. It belongs to the crucifer family. The plant has an upright stem with a lot of yellow flowers, which are located on scapes 5-8 mm long. It blooms from June to July, forms fruits in a shape of pods finish like a cover slip containing lightyellow spherical seeds which smooth surface. The fruits are ripe in August [12].

The seeds of this plant are rich in fatty oils (oleic, erucic, linoleic and stearic acids), steroids (brassicasterol, campesterol, sitosterol, cholesterin, methylenholesterin).

Mustard, like blessed milk thistle, is used in folk and official medicine as an effective medicinal plant for a long time. A lot of drugs are produced from its seeds for the treatment of various diseases [13]. Mustard, like blessed milk thistle, is used in folk and official medicine as an effective medicinal plant, not for one Millennium. Recently from the seeds of mustard a lot of drugs was produced for the treatment of various diseases. It is therefore important to know how the raw material of this plant meets the requirements for processing or drugs and other use, that is, what chemical elements and in what quantities are accumulated during the period of cultivation in the Kyiv region. That was the purpose of our research. 
The commercial use of this plant is various, but the article deals the medicinal application. Its medicinal raw materials are seeds, from which mustard oil is obtained. The degreased cake from mustard fruits is called.

The next research object - dragonhead, a unique plant, which obtained its name due to the shape of a flower (corolla) that resembles the head of a snake or dragon. Depending on the species this perennial or annual plant spread in Europe and Siberia, Central Asia, Mongolia and China. The plants occur as wild and are called by the gardeners in different ways: Melissa Turkish, drakonhead, blue pipewort, honey cake, because it is a good honey plant [14].

There are several species however in the experiments the most claimed in pharmacology Moldovian dragonhead and Austrian dragonhead were studied. (Dracocephalum (D) moldavica L.) (it is also called "Turkish balm") is an annual herbaceous plant belonging to the mint family Labiatae (Lamiaceae). Its homeland is considered to be South Siberia and China, although as wild it occurs in the countries of Central Asia and Eastern Europe. This plant is cultivated mainly in Eastern Siberia, Altai, Bulgarian as an oil-bearing crop, and as a valuable honey plant [15]. In recent years, the interest to Moldovian dragonhad increased significantly - this plant can be found in botanical collections in the overwhelming majority of botanical gardens and home plots, this plant production plantations appeared in Steppe, foreststeppe and foreat areas of Ukraine [16].

D. moldavica is a valuable introducent, with a rather wide range of application production. It is a medicinal plant. Its infusions and extracts from the above ground part are used as anti-inflammatory and anesthetic under the headache, neuralgia, tachycardia, hypertonia, insomnia, and rheumatism. Oil citral that is widely used as an aromatizer in the food and cosmetic industries is obtained from the plants. The useful property of dragonhead is a large amount of therapeutic medicinal ether oil. Moldovian dragonhead has a smell like lemon balm introduced into the inland medicine; its herb is used as an anesthetic.

The Austrian dragonhead population is not numerous, its biomorphological characteristic is hemicryptophyte. This is a perennial herb aqueous plant with almost upright, branched stems 20$60 \mathrm{~cm}$ high. It blossoms in May-July, fruits in JuneAugust, propagated by seeds only [17].
Austrian dragonhead has healing properties. It stimulates appetite and enhances digestion. Infusion of its plants is used to treat neuralgia, headache, and catarrhal diseases, toothache. Fresh crushed leaves accelerate the healing of wounds and contusions. Compresses help to treat rheumatism.

All these cultures are widely utilized for the manufacturing of drugs, so interest in them on the part of the processing industry and producers is high.

Turning directly to the results of the analysis presented in the table: the accumulation of heavy metals in the seeds of blessed milk thistle and products of their processing (oils), seeds of white mustard and black mustard, plants Moldovian and Austrian dragonhead (dry vegetative mass) on the average for the three years of cultivation (2012-2014), it should be noted that they have been determined by CTN MSS 42-4.0: 2008 [18].

The analysis of the data in the table concerning the determination of the content and concentration of chemical elements in blessed milk thistle plants has shown that the accumulation of the magnesium $(\mathrm{Mg})$ compounds seeds at the average for three growing seasons was: in the seeds $-1983.75 \mathrm{mg} / \mathrm{kg}$ in oil $-3.08 \mathrm{mg} / \mathrm{kg}$. The data about the seed content is presented below (see Table).

Magnesium belongs to the alkaline-earth metals. Its compounds are involved in photosynthesis. Taking into consideration that the magnesium permissible coefficient in dry vegetative mass of medicinal plants is not determined, and the daily requirement of an adult in this element is $-300-400 \mathrm{mg} / 100 \mathrm{~g}$, it is obvious that its quantitative content in the blessed milk thistle seeds is insignificant, because the experiments were carried out without feeding plants.

With regard to black mustard plants the similar analysis shows that by the accumulation of magnesium (the content in the seeds), on the average for the research years they exceeded those of white mustard by $92.7 \%$.

Among the plants of the various dragonhead species this difference was not so essential - the magnesium content prevailed in biological dry raw materials of the plants of Moldovian dragonhead by $27.04 \mathrm{mg} / \mathrm{kg}$ in compariso to those of Austrian dragonhead. 


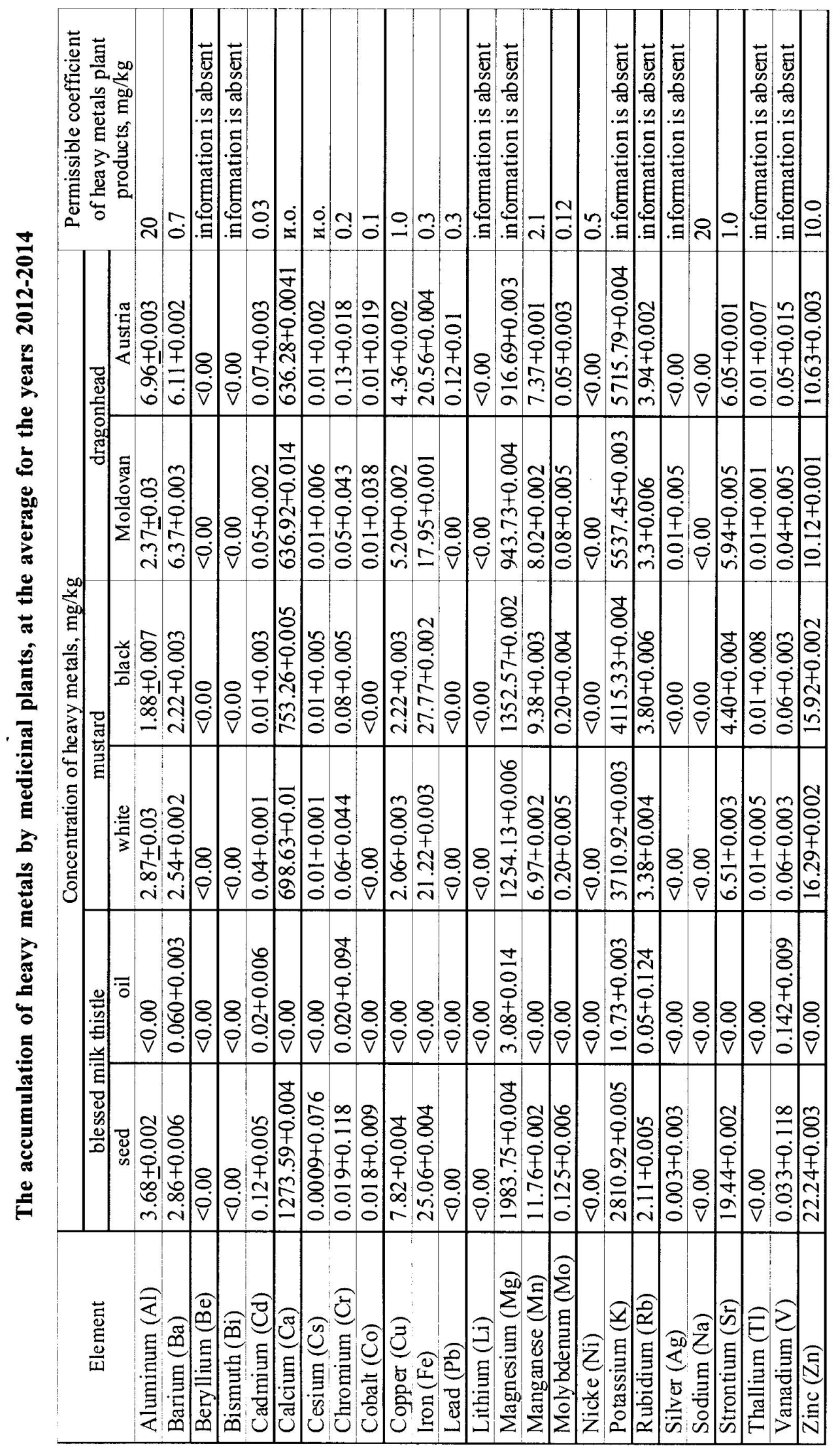


The research showed that the concentration of certain chemical elements in the seeds and vegetative dry mass of the medicinal plants that grow on the soils of the Kyiv region exceeded the permissible coefficient established for the raw material for processing. The cadmium (Cd) compounds in the seeds of blessed milk thistle appeared to exceed the rate by $0.09 \mathrm{mg} / \mathrm{kg}$ on the average for the cultivation years. The concentration of this element in oil was within the permissible coefficient $-0.01 \mathrm{mg} / \mathrm{kg}$ below the rate, as well as in the black mustard seeds, whereas in those of white mustard and in the dragonhead dry vegetative mass the accumulation of cadmium compounds exceeded the rate. Cadmium is one of the most toxic heavy metals, which belongs to the 2 nd class of danger ("high dangerous substances"). Like many other heavy metals, it has an obvious tendency to be accumulated in the organism - during the period of its half-life which is $10-35$ years. By 50 years its total weight content in the human organism can achieve 30-50 mg [19]. The concentration of the iron $(\mathrm{Fe})$ compounds in the seeds and dry vegetative mass of the studied cultures exceeded considerably PC - more than by $21 \mathrm{mg} / \mathrm{kg}$ at the average for the three growing years in the seeds of blessed milk thistle, by 20.92 and $27.47 \mathrm{mg} / \mathrm{kg}$ in those of white and black mustard respectively and in the dry vegetative weight mass of Moldovian and Austrian dragonhead by 17.65 and $20.26 \mathrm{mg} / \mathrm{kg}$ respectively. After the thermal processing of oil the concentration of this element has decreased the value less than the sensitivity threshold of analytical instruments. In living organisms, iron is an important microelement that catalyzes the processes of the oxygen exchange (respiration). The main intercellular iron stores is a globular protein complex - ferreting. Iron deficiency displays itself as a disease of the organism: chlorosis in plants and anemia in animals. The excessive accumulation of iron in the organism causes a toxic effect. The iron overdosing stimulates the production of free radicals, inhibits the organism antioxidant system, and probably, causes the atherosclerosis development [20].

The experimental plant objects are characterized by the rather high manganese (Mn) content that is more than by $17 \%$ higher than the permissible coefficient in the blessed milk thistle seeds, by $30 \%$ than in those of white mustard, by $22 \%$ than in black mustard, by $26 \%$ than in Moldavia and by $28 \%$ than in Austrian. Manganese is one of the most important microelements and occurs in almost all the plant and living organisms. It enhances the processes of blood formation in organisms. However, the excess of manganese compounds causes a toxic effect on the human organism. An obviously expressed poisoning indicates nerve damage with a characteristic syndrome of manganese Parkinsonism.

In samples of seeds of milk thistle the strontium ( $\mathrm{Sr}$ ) compounds concentration exceeded the permissible coefficient more than by 18 times whereas in the product of seeds processing (oil) it was not found. Probably, under the influence of the cold pressing (centrifugation) the strontium compound turned in to the inaccessible form and therefore did not penetrate into the oil (see table).

The plants of other crops accumulated significantly less strontium, but they also exceeded the rate of this element content: the seeds of white and black mustard by 5 and 3 times respectively, and the dry dragonhead vegetative mass almost by 5 times.

Strontium enters plants from soil, while into the organism of animals and human beings with food, water, etc. Soluble strontium compounds are well absorbed in the intestine (10-60\%), and poorly soluble - about $1 \%$. Strontium is accumulated in animals and human beings in the bony tissue. Thus, it is an osteotropic element [21].

The importance of the strontium in the vital activity of animals and plants is not considerable. However, this microelement is always present in the organism as a permanent calcium satellite, partially substituting it. The excessive strontium level in the human's organism causes the affection of a bone tissue, an increase bone of fragility and to rapid destruction of teeth. Afterwards, liver and blood are affected [22].

The zinc compounds in plants increase their heat, drought and cold resistance, action of enzymes comprising the enzyme systems taking part in respiration, synthesis of proteins and auxins play an important role in regulation of growth processes. The zinc importance for the plants growth is closely linked with its participation in the nitrogen metabolism. Under the influence of zinc the synthesis of sugars and starch improves as well as 
increases the total content of carbohydrates, proteins, ascorbic acid and chlorophyll. The excess of zinc in plant top-dressing occurs rather rarely. High zinc content in soil decreases the plants ability to absorb copper compounds.

The zinc compounds concentration in the studied medicinal crops samples appeared high, especially in the seeds of blessed milk thistle (by $12.24 \mathrm{mg} / \mathrm{kg}$ ), in those of white and black mustard by 6.29 and $5.92 \mathrm{mg} / \mathrm{kg}$ respectively above the permissible rate on the average for the three cultivation years whereas in the dry vegetative mass of dragonhead this element content is almost absent.

Such elements as aluminum (Al), cobalt (Co), chromium $(\mathrm{Cr})$ were found in the medicinal plants seeds and dry vegetative mass, but within the permissible concentrations.

According to the results of the analysis of oil from the blessed milk thistle seeds one can state that the raw material processing effects significantly the heavy metals concentration in the end product - they remain mostly in the cake.

As a result, it should be noted that the heavy metals are natural earth's crust components and are generally present in all the ecological matrices. Nevertheless, the HM concentration increased by several times in certain ecosystems as a result of anthropogenic activity. The environmental contamination by heavy metals continues to acquire global character mainly because of the toxicological risks for human health associated with such metals. However, heavy metals are essential components of living organisms and in high concentrations exhibit toxicity.

As the studies results have shown the soils of the Kyiv region are quite suitable for the medicinal plants cultivation, because the concentration of heavy metals, which they accumulate during the growing season as a whole is within the permissible level, and the presence of elements, the concentration of which exceeds the above mentioned one, demands regulation by the agroecological methods of research.

\section{Conclusions}

1. As the standard and legislative documents for many chemical elements that relate to heavy metals, do not contain permissible coefficients of their content in the medicinal plants dry vegetative mass, it is actual to initiate comprehensive research with the involvement of the relevant profiles experts for the establishment of such a gradation.

2. The plants of blessed milk thistle, white and black mustard, Moldovian and Austrian dragonhead in the conditions of the Kyiv region accumulate such heavy metals as barium, iron, manganese, strontium, zinc, copper in the quantities, exceeding the permissible level that, indicates a partial contamination of the soils in the region.

3. The studies have shown that the concentration of most heavy metals decreased in the blessed milk thistle processing product (oil) to a value which is less than the sensitivity threshold of analytical instruments, testifies the perceptiveness of the medicinal plants growing in the Kyiv region for industrial processing.

4. Specific features of biological medicinal herbs - mustard and dragonhead - display their specificity in the quantity chemical elements accumulation, which can be used in the breeding process.

\section{REFERENCES}

1. Lyebyeda A.P., ed. Catalogue of Medicinal Plants of the Botanical Gardens and Arboretums in Ukraine. Handbook. Kyiv, Akademperiodika Publ., 2009. 159 p. (in Ukrainian).

2. Dospyekhov V.A. Methods of field experience (with the fundamentals of statistical processing of the results of research). Moscow, Agropromizdat Publ., 1985. 351 p. (In Russian).

3. Drugs. Appropriate practice of the cultivation and collection of the primary raw material of the plant origin, ST-H MSS 42-4.5: Official publication. Kyiv, Ministry of Health of Ukraine, 2012. 13 p. (In Ukrainian).

4. Ezhov V.N., Rudnik-Ivashchenko O.I., Shobat D.M., Yaruta O.Y. Research organizational and economic aspects of the medicinal and oil-bearing crops cultivation in Ukraine. Journal of agricultural science, 2014, vol. 11, pp. 16-21. (In Ukrainian).

5. Gubanov I.A., Kiseleva K.V., Novikov V.S., Tikhomirov V.N. The illustrated keys to plants of Middle Russia. In 3 vols. Vol 3: the Arts of scientific publications, the Institute technologist. Research, 2004, vol. 3, 413 p. (In Russian).

6. Heansen P., Ryugo K., Ramos D.E., Fitch L. Influence of cropping on $\mathrm{Ca}, \mathrm{K}, \mathrm{Mg}$, and carbohydrate status of 'French' prune trees grown on potassium limited soils. Am. Soc. Hortic. Sc., 2010, 3, pp. 511-515. (In English). 
7. Ivashchenko A.A. Green Neighborury. Plant Physiology and Genetics, 2014, vol. 45, pp. 179-181. (In Ukrainian).

8. Kislichyenko V.S., Pospelov S.V., Samorodov V.N., Gudzenko A.P. Blessed thistle - from the introduction to the use: monography. Poltava, Poltava literary, 2008. 288 p. (In Ukrainian).

9. Medicinal grasses looking for arable land. Available at: http://www.spil.ucoz.ua/news/ 2009-03-27-47.

10. Medicinal plants their distribution and use. Available at: http://www.likarski-travi.ks.ua. (In Russian).

11. Myelnichuk Y.P. Cadmium ions effect on the cell division and in plant growth. Kyiv, Scientific opinion, 1990. 148 p. (In Ukrainian).

12. Newman Arnold. The light of the world/ rainforest - the most endangered biocoenosis on the ground. Moscow, Mir Publ., 1989. 334 p. (In Russian).

13. Ostapko V.M., Zubtsova T.V. Introduction of rare species of flora of the southeast of Ukraine. Sevastopol, Weber Publ., 2006. 296 p. (In Russian).

14. Ovyechka S.V. Biological jocularities and characteristics of Dracocephalum moldavica $L$. valuable for economy in the conditions of the Low Dnieper in the Kherson region: Cnad. biol. sci. abs. diss. Yalta, 2003. 20 p. (In Russian).

15. Production of drugs of the plant origin / Manual ST-H magnetic memory 42-4.0: 2008 "Drugs.
Appropriate manufacturing practice”, Appendix 7. Moscow, Ministry of Health of Ukraine, 64 p. (In Ukrainian). 16. Rabotyogov V.D., Svidenko L.V., Derevyanko V.N., Boiko M.F. Oil-bearing and medicinal plants, introduced in the Kherson region (ecological and biological peculiarities and traits valuable economy). Kherson, Ailanthus Publ., 2003. 288 p. (In Russian).

17. Rudnik-Ivashchenko O.I., Yaruta O.Y. Study of standart of sowing belladonna (Atropa belladonna $L$.) in order to introduce into culture in the conditions of the Forest-Steppe of Ukraine. Collection of scientific papers of Uman National University of horticulture. Uman, 2015, pp. 171-175. (In Ukrainian).

18. Sanitary standards of permissible concentrations of toxic substances in the soil. SanPiN 42-126-4433-87. Methods of the determination of contaminants in the soil. Official publication. Moscow, 1987. 64 p. (In Russian).

19. Vorobyeva L.A., ed. Theory and practice of chemical analysis of soils. Moscow, GEOS Publ., 2006. 400 p. (In Russian).

20. Trachtenberg I.M. Heavy metals in the environment: modern hygienic and toxicological aspects. Minsk, Science and technology Publ., 1994. 286 p. (In Russian).

21. Mineev V.G., Sichev V.H., Ameljanchik T.N., \& Bolsheva O.A. Workshop on agricultural chemistry: Tutorial. Moscow, Publishing house of Moscow State University, 2001. 689 p. (In Russian).

\title{
ОСОБЕННОСТИ НАКОПЛЕНИЯ ТЯЖЕЛЫХ МЕТАЛЛОВ В РАСТЕНИЯХ ЛЕКАРСТВЕННЫХ КУЛЬТУР В УСЛОВИЯХ ЛЕСОСТЕПИ
}

\section{Ольга Ивановна Рудник-Иващенко}

\author{
Доктор сельскохозяйственных наук, \\ заместитель директора по научно-инновационной работе, \\ Институт садоводства, \\ Национальная академия наук Украины \\ rudnik2015@ukr.net \\ ул. Садовая, 6, 03027 г. Киев, Украина
}

\section{Людмила Николаевна Михальская}

Кандидат биологических наук,

Институт физиологии растений и генетики, Национальная академия наук Украины

VictorSchwartau@gmail.com

ул. Васильковская, 31/17, 03022 г. Киев, Украина 


\section{Виктор Валентинович Швартау}

Доктор биологических наук, чл.-корр. Национальной академии наук Украины, Институт физиологии растений и генетики, Национальная академия наук Украины VictorSchwartau@gmail.com ул. Васильковская, 31/17, 03022 г. Киев, Украина

Аннотация. В работе проведен мониторинг концентрации тяжелых металлов в окружающей среде, который необходим для проведения своевременных мероприятий, направленных на сохранение чистоты окружающей среды и здоровья человека. Также получена информация о содержании тяжелых металлов в сухой вегетативной массе лекарственных растений.

Ключевые слова: лекарственные культуры, змееголовник, горчица, допустимый коэффициент, сухая вегетативная масса, химические элементы. 